\title{
UNCONVENTIONAL TECHNIQUE USED TO MANUFACTURE POROUS HIGH-STRENGTH GLASS FOAM
}

\author{
LUCIAN PAUNESCU*1, SORIN MIRCEA AXINTE ${ }^{1,2}$, MARIUS FLORIN \\ DRAGOESCU ${ }^{2}$, BOGDAN VALENTIN PAUNESCU ${ }^{3}$, FELICIA COSMULESCU ${ }^{4}$ \\ ${ }^{1}$ Daily Sourcing \& Research SRL, 95-97 Calea Grivitei, sector 1, Bucharest 010705, \\ Romania \\ ${ }^{2}$ University "Politehnica" of Bucharest, Faculty of Applied Chemistry and Materials \\ Science, 1-7 Gh. Polizu street, sector 1, Bucharest 011061, Romania \\ ${ }^{3}$ Consitrans SA, 56 Polona street, sector 1, Bucharest 010504, Romania \\ ${ }^{4}$ Cosfel Actual SRL, 95-97 Calea Grivitei, sector 1, Bucharest 010705, Romania
}

\begin{abstract}
The paper presents experimental results obtained in the manufacturing process of porous high-strength glass foam for thermal insulation in buildings made of glass waste and kaolin clay as raw materials and dolomite as a foaming agent. The paper's originality is the use of the unconventional microwave heating technique. The best product manufactured by this technique was that sintered at $1050{ }^{\circ} \mathrm{C}$ using $18 \mathrm{wt} . \%$ kaolin clay and $3.5 \mathrm{wt} . \%$ dolomite. The product characteristics were: the apparent density of $0.66 \mathrm{~g} \cdot \mathrm{cm}^{-3}$, the thermal conductivity of $0.155 \mathrm{~W} / \mathrm{m} \cdot \mathrm{K}$, the compressive strength of $5.3 \mathrm{MPa}$ and a microstructural homogeneity with pore size between $0.20-0.50 \mathrm{~mm}$.
\end{abstract}

Keywords: high-strength glass foam, glass waste, kaolin clay, dolomite, microwave heating, low specific energy consumption

\section{INTRODUCTION}

Glass waste and especially post-consumer container glass represents a large amount of waste, whose annual generation rate is constantly growing worldwide. Closed circuit recycling for the manufacture of new glass is the most common form of glass waste recovery. Because this operation includes the color separation of glass, the closed-loop recycling process is considered too expensive and the use of glass foam as a replacement for some building materials becomes an efficient solution and an adequate solution in ecological and energy terms. The properties of glass foam (light weight, low thermal conductivity, high compressive strength, fire resistance, water and steam resistance, resistance to rodents, insects, bacteria and acids, freeze-thaw resistance, etc.) make it very attractive for using as building materials [1].

For several decades, the manufacturing process of various types of glass foam has been the concern of industrial manufacturers, such as Misapor Switzerland, Pittsburgh Corning, Geocell Schaumglas, Glapor Werk Mitterteich and others. The raw material is mainly composed of container glass and flat glass waste and several types of materials such as carbon black, coal dust, calcium carbonate, silicon carbide, etc. are used as foaming agent. Various other recipes and new manufacturing techniques are being tested experimentally by numerous teams of researchers in the world $[2,3]$.

\footnotetext{
* Corresponding author, email: lucianpaunescu16@gmail.com

(C) 2021 Alma Mater Publishing House
} 
One of the techniques used to produce glass foam is to use glass waste as a raw material and natural dolomite as a foaming agent. Given the low cost of dolomite (35-180 USD/ton) compared to that of calcium carbonate (1000-1600 USD/ton) and silicon carbide (400-1200 USD/ton) [4-6] the interest in using this material is justified.

The literature presents several information on the processes of manufacturing glass foam of glass waste and dolomite. According to [7], a mixture of colorless soda-lime glass waste and natural dolomite (3-5 wt.\%) as raw material and foaming agent, respectively, was heated up to $600{ }^{\circ} \mathrm{C}$ with $5-10{ }^{\circ} \mathrm{C} / \mathrm{min}$ and then, up to $800-900{ }^{\circ} \mathrm{C}$ with $1.7-2.5^{\circ} \mathrm{C} / \mathrm{min}$. The dolomite decomposition begins at about $800{ }^{\circ} \mathrm{C}$ and reaches the maximum value at about $900{ }^{\circ} \mathrm{C}$. For $5 \%$ dolomite ratio, the thermal conductivity had values between $0.29-0.55 \mathrm{~W} / \mathrm{m} \cdot \mathrm{K}$. The pore size was between $0.1-1.2 \mathrm{~mm}$ at $800{ }^{\circ} \mathrm{C}$ and between $0.5-0.8 \mathrm{~mm}$ at $900{ }^{\circ} \mathrm{C}$.

A manufacturing method of glass foam from glass waste, coal fly ash (20 wt. \%) and a sludge based on dolomite and calcite as a foaming agent (1-2 wt.\%) is presented in [8]. The sintering temperature was $850{ }^{\circ} \mathrm{C}$. The main glass foam characteristics were: the apparent density of $0.36-0.41 \mathrm{~g} \cdot \mathrm{cm}^{-3}$ and the compressive strength between 2.4-2.8 MPa.

Another use of natural dolomite as a foaming agent is shown in the paper [9]. Dolomite was one of the variants tested in the paper (egg shell and calcite, respectively). The weight ratio of dolomite was 3\%. The raw material used was the panel and funnel glass from the cathode ray tube (CRT). The sintering and foaming temperature was low $\left(650-750{ }^{\circ} \mathrm{C}\right)$. The glass foam had an apparent density of $0.29 \mathrm{~g} \cdot \mathrm{cm}^{-3}$ and a compressive strength of 2.34 MPa.

A technique for manufacturing a foamed bioactive silicate scaffold for medical purposes using dolomite as a foaming agent is presented in [10]. A specially made silicate glass containing $\mathrm{SiO}_{2}(47.5 \%), \mathrm{Na}_{2} \mathrm{O}(10 \%), \mathrm{K}_{2} \mathrm{O}$ (10\%), $\mathrm{MgO}(10 \%), \mathrm{CaO}(20 \%), \mathrm{P}_{2} \mathrm{O}_{5}(2.5 \%)$ was used, by melting at $1500{ }^{\circ} \mathrm{C}$, cast in water for fritting and then, after cooling, ground. The weight proportion of glass was $98 \%$ and the dolomite proportion was $2 \%$. The mixture pressed into a mold was sintered at 800 and $850^{\circ} \mathrm{C}$ in an electric oven. The apparent density was 0.45 $\mathrm{g} \cdot \mathrm{cm}^{-3}$ for the sample heated at $800{ }^{\circ} \mathrm{C}$ and $0.91 \mathrm{~g} \cdot \mathrm{cm}^{-3}$ for the sample heated at $850{ }^{\circ} \mathrm{C}$. The porosity values were 83.1 and $65.5 \%$, respectively. The compressive strength had the value of $3.9 \mathrm{MPa}$ corresponding to the heat treatment at $850^{\circ} \mathrm{C}$ and $1.3 \mathrm{MPa}$ for the sample heated at $800{ }^{\circ} \mathrm{C}$.

The paper [11] presents results of the experimental manufacture of granulated glass foam as a lightweight aggregate usable in concrete. The raw material was selected from the municipal waste by disposing of hazardous waste CRT glass and fluorescent lamp envelopes. Dolomite powder was adopted as a foaming agent (in a weight ratio between $1-4 \%)$ and tapioca starch gel $(35 \%)$ as an organic binder. The finely ground mixture was compacted by dry pressing into disks with a diameter of $5 \mathrm{~mm}$. The sintering of the pressed mixture was performed at 750 and $800{ }^{\circ} \mathrm{C}$ respectively, with a heating rate of $5{ }^{\circ} \mathrm{C} / \mathrm{min}$. Experimentally, it was found that the most appropriate weight proportion of dolomite was $3 \%$ and the optimum sintering temperature was $750{ }^{\circ} \mathrm{C}$. The bulk density was $0.39 \mathrm{~g} \cdot \mathrm{cm}^{-3}$ and the porosity was $76 \%$. The pore size of the glass foam was very small (between $10-100 \mu \mathrm{m})$. The tests performed at $800{ }^{\circ} \mathrm{C}$ led to an inhomogeneous distribution of the pores and their uneven dimensions. The determination of the mechanical and thermal characteristics could not be performed due to the very small dimensions (less than $10 \mathrm{~mm}$ ) of the manufactured glass foam granules.

According to the literature [12], the use of organic binders (gypsum, geopolymers or starch) leads to a reduction in bulk density and thermal conductivity, but at the same time affects the mechanical strength of the material. In the case of manufacturing products (e.g. glass foams) usable as replacements of existing building materials, low values of density and thermal conductivity are even required ensuring an excellent thermal insulation, but a very poor mechanical strength (less than $1 \mathrm{MPa}$ ) is not indicated. Also, especially in the case of starch, the water resistance is low and there is a great instability of mechanical properties when changing environmental conditions, which is totally not suitable for construction materials.

Another method of producing a block foam glass using glass waste, dolomite as a foaming agent and sodium silicate solution (water glass) is presented in the paper [13]. The proportion of dolomite varied between 3-5\% and that of water glass between $4-6 \%$. The sintering temperature had values between $810-825{ }^{\circ} \mathrm{C}$. The characteristics of the glass foam were: the apparent density of $0.43 \mathrm{~g} \cdot \mathrm{cm}^{-3}$, the thermal conductivity of 0.092 $\mathrm{W} / \mathrm{m} \cdot \mathrm{K}$ and the compressive strength of $2.6 \mathrm{MPa}$. 
According to [14], testing the influence of the addition of clay powder in a finely ground mixture composed of soda-lime glass waste and dolomite powder as a foaming agent was performed. Three variants have experimented, one of reference with glass waste $(85 \%)$ and dolomite $(15 \%)$ and two, in which the proportion of clay addition was successively 9.09 and $16.66 \%$ and the dolomite proportion was successively reduced to 13.63 and $12.5 \%$, respectively. The sintering temperature had in all three variants the following values: 1000, 1040 and $1075^{\circ} \mathrm{C}$. The results showed the general tendency of decreasing the bulk density and, respectively, of increasing the porosity with increasing the sintering temperature, but the addition of clay negatively influenced the two physical characteristics of the foamed products. Compared to the minimum density value in the reference variant $\left(0.77 \mathrm{~g} \cdot \mathrm{cm}^{-3}\right.$ at $\left.1075{ }^{\circ} \mathrm{C}\right)$, it reached $0.95 \mathrm{~g} \cdot \mathrm{cm}^{-3}$ for $9.09 \%$ clay and $1.12 \mathrm{~g} \cdot \mathrm{cm}^{-3}$ for $16.66 \%$ clay. Instead, the maximum porosity in the reference variant $\left(37.5 \%\right.$ at $\left.1075{ }^{\circ} \mathrm{C}\right)$ reached $52.5 \%$ for $9.09 \%$ clay and $62 \%$ for $16.66 \%$ clay. The highest compressive strength was $2.3 \mathrm{MPa}$ at $1075^{\circ} \mathrm{C}$ for $16.66 \%$ clay, $1.5 \mathrm{MPa}$ for $9.09 \%$ clay and $1.4 \mathrm{MPa}$ for the reference variant (also, at $1075^{\circ} \mathrm{C}$ ).

All experiments described in papers $[7-11,13,14]$ were performed by conventional heating methods. The paper [15] presents results of experiments performed in the Romanian company Daily Sourcing \& Research for the experimental manufacture of a glass foam from container glass waste ( $80 \%$ green glass and $20 \%$ colorless and amber glass), natural dolomite as a foaming agent and water addition, the heating method being unconventional using the microwave energy. The glass waste (ground and sieved below $130 \mu \mathrm{m}$ ) and the foaming agent were mixed and wet pressed into a metal mold and then, removed from the mold, the pressed mixture being introduced in the microwave oven. The glass waste ratio was between $94-97 \mathrm{wt} . \%$ and the dolomite powder ratio between 3-6 wt.\%. The water addition was kept constant (16 wt.\%) in all tested experimental variants. The sintering temperature varied between $820-848^{\circ} \mathrm{C}$ and the time process in the range $46-52 \mathrm{~min}$. The specific energy consumption had values between $1.32-1.48 \mathrm{kWh} / \mathrm{kg}$. The glass foam samples characteristics showed that they are suitable for using as an insulating material in building: the apparent density between $0.30-0.32 \mathrm{~g} \cdot \mathrm{cm}^{-3}$, the porosity between $85.5-86.5 \%$, the thermal conductivity in the range $0.064-0.067 \mathrm{~W} / \mathrm{m} \cdot \mathrm{K}$, the compressive strength between 2.2-2.6 MPa, the water absorption between $0.8-1.2 \%$ and a microstructural homogeneity in all variants with pore size from $0.8-1.5 \mathrm{~mm}$ up to $1.8-3.3 \mathrm{~mm}$.

The current paper aims to test a manufacturing recipe of glass foam, including colorless container glass waste and commercial clay powder as raw materials and dolomite powder as a foaming agent in order to increase the mechanical strength of glass foam as a potential building material. The heating technique used in experiments was unconventional based on the microwave energy.

\section{METHODS AND MATERIALS}

\subsection{Methods}

The basic principle of foaming a silicate-based powder mixture is the incorporation in the mixture mass of a foaming agent, which by heating at high temperature $\left(750-1150{ }^{\circ} \mathrm{C}\right)$ releases a gas or a gaseous compound following a chemical reaction (by several times, decomposition or oxidation). It is necessary a correlation between the temperature range in which the reaction occurs and the temperature at which the mixture softening begins and the viscosity decreases to a value at which the gas can spread in its mass, but cannot leave it, being blocked in form of bubbles. The cooling of the material transforms the bubbles into pores forming a typical porous structure [1]. The heating technique commonly used both in industrial production and in the many experiments conducted in the world, is conventional (by electrical resistances or burning fossil fuels).

Unlike this technique, the Daily Sourcing \& Research Company has adopted the microwave heating in the last four years. Although known for almost 90 years, microwaves have been used to a very small extent and especially in drying or heating processes at low temperature. According to [16], in the last two decades it has been experimentally found that several types of materials (ceramics, organics, polymers, metals, glasses, etc.) are suitable for efficient microwave heating. However, the industrial application of this heating technique is delayed, being still in experimental stages.

The foaming process using natural dolomite as a foaming agent is produced by the thermal decomposition of the dolomite in two stages, according to the thermogravimetry-differential thermal (TG-DTA) analysis previously determined. The first stage begins at $440{ }^{\circ} \mathrm{C}$ and the second begins at $740{ }^{\circ} \mathrm{C}$. The two stages occur according the following chemical reactions $[17,18]$ : 


$$
\begin{gathered}
\mathrm{CaMg}\left(\mathrm{CO}_{3}\right)_{2}=\mathrm{CaCO}_{3}+\mathrm{CO}_{2} \\
\mathrm{CaCO}_{3}=\mathrm{CaO}+\mathrm{CO}_{2}
\end{gathered}
$$

The carbon dioxide $\left(\mathrm{CO}_{2}\right)$ is the gaseous compound that is released and contributes to the foaming and the calcium oxide $(\mathrm{CaO})$ is incorporated in the mixture mass.

The experimental microwave equipment was based on the $0.8 \mathrm{~kW}$ Sharp type microwave oven manufactured in 2010 with a capacity of $25 \mathrm{~L}$ adapted for operation at high temperature (up to $120{ }^{\circ} \mathrm{C}$ ) existing in the company's experimental base. The constructive scheme of this equipment is shown in Figure 1. The pressed mixture (3) is placed freely on a metal plate (4) spaced at $20-25 \mathrm{~mm}$ from the bed of ceramic fiber mattresses at the base of the oven. A ceramic tube (5) made of a high microwave susceptible material $\left(\mathrm{SiC}\right.$ and $\left.\mathrm{Si}_{3} \mathrm{~N}_{4}\right)$ with $125 \mathrm{~mm}$-outer diameter, $100 \mathrm{~mm}$-height and $2.5 \mathrm{~mm}$-thickness wall is placed on the same ceramic fiber bed protecting the pressed mixture against the intensity of the microwave flow too active for the direct heating of a glass-based mixture. Partially, the microwave field is absorbed into the mass of the ceramic tube, which heats up rapidly and will indirectly transfer the heat to the mixture by thermal radiation. Predominantly direct microwave heating is initiated in the core of the material, which must have at least one microwave susceptible component. The microwave power is converted into heat and the core of the material becomes the hottest area. The heat is propagated volumetrically from the inside to the peripheral areas [19]. Thermal protection with ceramic fiber mattresses is very important during the heating process to avoid the heat loss outside the system. Selectivity is one of the basic characteristics of the direct microwave heating in order to obtain a high energy efficiency [20]. This means that only the material intended for heating receives the microwave power, not also the other components of the oven, as in the case of the conventional heating. The protection of the pressed mixture is also ensured in the upper area. A ceramic lid (2) of the same material as the ceramic tube, provided with a hole of about $30 \mathrm{~mm}$ for viewing the heated material, is placed above the upper opening of the tube and is thermally protected with ceramic fiber mattresses. The control of the thermal process is performed with a Pyrovar type radiation pyrometer (9) mounted above the oven at $400 \mathrm{~mm}$. The upper metal wall of the oven has a $30 \mathrm{~mm}$ hole on the same vertical axis as the ceramic lid.

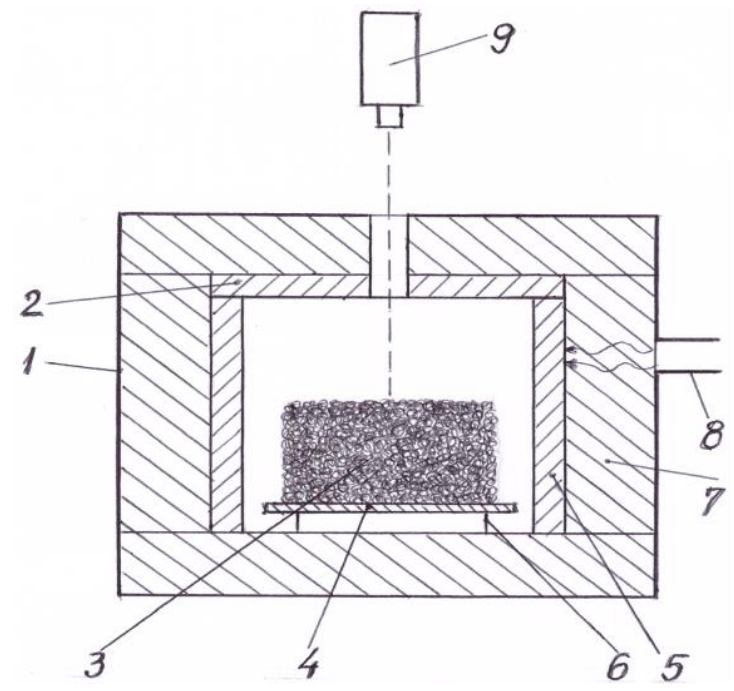

Fig. 1. The constructive scheme of the experimental equipment:

1 - $0.8 \mathrm{~kW}$-microwave oven; 2 - ceramic lid; 3 - pressed mixture; 4 - metal plate; 5 - ceramic tube; 6 - metal support; 7 - ceramic fiber thermal protection;

8 - waveguide; 9 - radiation pyrometer.

Images of overall used experimental equipment and details of its components were presented in previous works of the authors' team [21, 22].

\subsection{Materials}

The materials used in the experiments were colorless container glass waste, kaolin clay $\left(\mathrm{Al}_{2} \mathrm{O}_{3} \cdot 2 \mathrm{SiO}_{2} \cdot 2 \mathrm{H}_{2} \mathrm{O}\right)$ powder and dolomite $\left(\mathrm{CaMg}\left(\mathrm{CO}_{3}\right)_{2}\right)$ powder as a foaming agent. 
The glass waste was selected by color, broken, ground in a ball mill and sieved, the grain size being below 130 $\mu \mathrm{m}$. The chemical composition of glass waste [23] is shown in Table 1 .

Table 1. Chemical composition of raw material.

\begin{tabular}{|l|c|c|c|c|c|c|c|c|c|c|}
\hline \multicolumn{1}{|c|}{$\begin{array}{c}\mathrm{Raw} \\
\text { material }\end{array}$} & $\begin{array}{c}\mathrm{SiO}_{2} \\
\text { wt.\% }\end{array}$ & $\begin{array}{c}\mathrm{Al}_{2} \mathrm{O}_{3} \\
\text { wt.\% }\end{array}$ & $\begin{array}{c}\mathrm{Fe}_{2} \mathrm{O}_{3} \\
\text { wt.\% }\end{array}$ & $\begin{array}{c}\mathrm{Na}_{2} \mathrm{O} \\
\text { wt.\% }\end{array}$ & $\begin{array}{c}\mathrm{MgO} \\
\text { wt.\% }\end{array}$ & $\begin{array}{c}\mathrm{CaO} \\
\text { wt.\% }\end{array}$ & $\begin{array}{c}\mathrm{K}_{2} \mathrm{O} \\
\text { wt.\% }\end{array}$ & $\begin{array}{c}\mathrm{TiO}_{2} \\
\text { wt.\% }\end{array}$ & $\begin{array}{c}\mathrm{Cr}_{2} \mathrm{O}_{3} \\
\text { wt.\% }\end{array}$ & $\begin{array}{c}\mathrm{P}_{2} \mathrm{O}_{5} \\
\text { wt.\% }\end{array}$ \\
\hline $\begin{array}{l}\text { Colorless } \\
\text { container } \\
\text { glass }\end{array}$ & 71.70 & 1.90 & 0.01 & 13.30 & 1.00 & 12.00 & - & 0.01 & 0.05 & - \\
\hline $\begin{array}{l}\text { Clay } \\
\text { powder }\end{array}$ & 57.63 & 37.77 & 0.86 & - & 0.60 & 0.35 & 1.80 & - & - & 0.31 \\
\hline
\end{tabular}

The kaolin clay powder was purchased from the market and had the chemical composition [24, 25] shown in Table 1. The grain size was below $35 \mu \mathrm{m}$.

The dolomite powder was also purchased from the market and underwent a grinding operation in a $10 \mathrm{~kW}$ electrical laboratory device. The grain size at the end of this operation was below $40 \mu \mathrm{m}$.

\section{RESULTS AND DISCUSSION}

\subsection{Results}

Four manufacturing recipes of glass foam were adopted according to Table 2. Kaolin clay powder was added in the raw material mixture (between 12-21 wt.\%) as a partial replacer of glass waste whose weight proportion was between 75.3-84.9 wt.\%. The role of clay was to increase the mechanical strength of glass foam. This effect has been highlighted in several previous works [14, 21, 25]. The value of dolomite powder ratio varied in experiments in low limits between 3.1-3.7 wt.\%. To facilitate the cold pressing of the powder mixture, a constant amount of water addition (representing $20 \mathrm{wt} \%$ ) was used.

Table 2. Experimental variants prepared in the current study.

\begin{tabular}{|c|c|c|c|c|}
\hline Variant & $\begin{array}{c}\text { Colorless glass waste } \\
\text { wt. } \%\end{array}$ & $\begin{array}{c}\text { Clay powder } \\
\text { wt. } \%\end{array}$ & $\begin{array}{c}\text { Dolomite powder } \\
\text { wt. \% }\end{array}$ & $\begin{array}{c}\text { Water addition } \\
\text { wt. } \%\end{array}$ \\
\hline 1 & 84.9 & 12.0 & 3.1 & 20.0 \\
\hline 2 & 81.7 & 15.0 & 3.3 & 20.0 \\
\hline 3 & 78.5 & 18.0 & 3.5 & 20.0 \\
\hline 4 & 75.3 & 21.0 & 3.7 & 20.0 \\
\hline
\end{tabular}

Each variant was tested separately in the microwave oven. Unlike the experimentation methodology specific to conventional techniques, in which a temperature value is pre-established, the softened material being maintained at this temperature for foaming, in the case of the microwave radiation using, the increasing evolution of the heated material temperature is monitored, reaching the maximum value followed of the slow decrease of the temperature constituting the end of the heating process.

Because the ceramic fiber as a thermal insulator has a poor thermal inertia, after completing the heating a cooling process in the oven at a low speed occurs. The main functional parameters of the manufacturing process of glass foam are shown in Table 3.

Analyzing the data in Table 3, the high level of sintering/foaming temperature (between $1013-1072{ }^{\circ} \mathrm{C}$ ) is observed, which is due to the addition of clay. The weight ratio of clay has determined the value of this temperature. Thus, the maximum sintering temperature corresponded to the highest clay proportion (21 wt. \%) in the raw material mixture. Implicitly, the process time increased from 40 to $50 \mathrm{~min}$ and also the specific energy consumption from 0.89 to $1.10 \mathrm{kWh} / \mathrm{kg}$. Compared to other similar processes, the average value (around 1 $\mathrm{kWh} / \mathrm{kg}$ ) of the energy consumption is very economical, considering that the process temperature exceeds 1000 ${ }^{\circ} \mathrm{C}$ in all experimental variants.

Table 3. Main functional parameters of the manufacturing process of glass foam.

\begin{tabular}{l|l} 
Parameter & Variant
\end{tabular}




\begin{tabular}{|l|c|c|c|c|}
\hline & 1 & 2 & 3 & 4 \\
\hline $\begin{array}{l}\text { Raw material/glass foam } \\
\text { amount }(\mathrm{g})\end{array}$ & $485 / 470$ & $485 / 472$ & $485 / 475$ & $485 / 473$ \\
\hline $\begin{array}{l}\text { Sintering/foaming temperature } \\
\left({ }^{\circ} \mathrm{C}\right)\end{array}$ & 1013 & 1031 & 1050 & 1072 \\
\hline Heating time $(\mathrm{min})$ & 40 & 43 & 46 & 50 \\
\hline Average heating rate $\left({ }^{\circ} \mathrm{C} / \mathrm{min}\right)$ & 25.3 & 23.5 & 22.4 & 21.0 \\
\hline Average cooling rate $\left({ }^{\circ} \mathrm{C} / \mathrm{min}\right)$ & 6.6 & 6.4 & 6.5 & 6.5 \\
\hline Index of volume growth & 1.30 & 1.40 & 1.55 & 1.80 \\
\hline $\begin{array}{l}\text { Specific energy consumption } \\
(\mathrm{kWh} / \mathrm{kg})\end{array}$ & 0.89 & 0.95 & 0.99 & 1.10 \\
\hline
\end{tabular}

The physical, mechanical, thermal and morphological characteristics of the glass foam samples were measured by common methods. The apparent density was measured by the gravimetric method [26] and the porosity was calculated by the method of comparing the true and apparent density [27].

The compressive strength was determined using aTA.XTplus Texture Analyzer of Stable Micro Systems (ASTM C552-17) [28] and the thermal conductivity was measured by the heat-flow meter method (ASTM E1225-04 standard) [29]. The water absorption was determined by the water immersion (for 24 hours) method (ASTM D570 standard) [30]. The samples microstructure was examined with an ASONA 100X Zoom Smartphone Digital Microscope.

The main physical, thermal, mechanical and morphological characteristics of glass foam samples are shown in Table 4.

Table 4. Main physical, thermal, mechanical and morphological characteristics of glass foam samples.

\begin{tabular}{|c|c|c|c|c|c|c|}
\hline Variant & $\begin{array}{c}\text { Apparent } \\
\text { density } \\
\left(\mathrm{g} \cdot \mathrm{cm}^{-3}\right)\end{array}$ & Porosity & $\begin{array}{c}\text { Thermal } \\
\text { conductivity } \\
(\%)\end{array}$ & $\begin{array}{c}\text { Compressive } \\
\text { strength } \\
(\mathrm{MPa})\end{array}$ & $\begin{array}{c}\text { Water } \\
\text { absorption } \\
(\%)\end{array}$ & Pore size \\
\hline 1 & 0.63 & 70.0 & 0.153 & 2.8 & 4.8 & $0.10-0.30$ \\
\hline 2 & 0.67 & 68.1 & 0.158 & 3.9 & 5.3 & $0.10-0.40$ \\
\hline 3 & 0.66 & 68.6 & 0.155 & 5.3 & 6.7 & $0.20-0.50$ \\
\hline 4 & 0.69 & 67.3 & 0.161 & 6.2 & 7.6 & $0.30-0.60$ \\
\hline
\end{tabular}

Cross sections of the products obtained by using the four experimental variants are presented in Figure 2. According to the pictures, the products made with lower proportions of clay and at lower temperature values have a finer and more compact structure compared to products made with high proportions of clay and at higher temperatures.

Although the pore size is increasing, the compressive strength does not decrease, but increases, confirming the theory set out in [1] according to which there is no correlation between pore size and mechanical strength of a porous material. In the microstructure of the porous material, the role of the cell walls with a superior mechanical resistance can become decisive, a fact found in this experiment. So, despite the increase of the total volume of the goals in the structure of the porous material (in the case of samples 3 and 4) the physical consistency of its solid part determines the significant improvement of the compressive strength. Also, by increasing the pore size from sample 1 to sample 4, the value of the apparent density increases very low, although it should decrease. Similarly, thermal conductivity increases only to a very small extent. According to the data in Table 4, the apparent density and thermal conductivity had values with relatively small variations between the four variants (between $0.63-0.69 \mathrm{~g} \cdot \mathrm{cm}^{-3}$ and $0.153-0.161 \mathrm{~W} / \mathrm{m} \cdot \mathrm{K}$, respectively). In the same way, the value of the products porosity has evolved (between 67.3-70.0\%). 


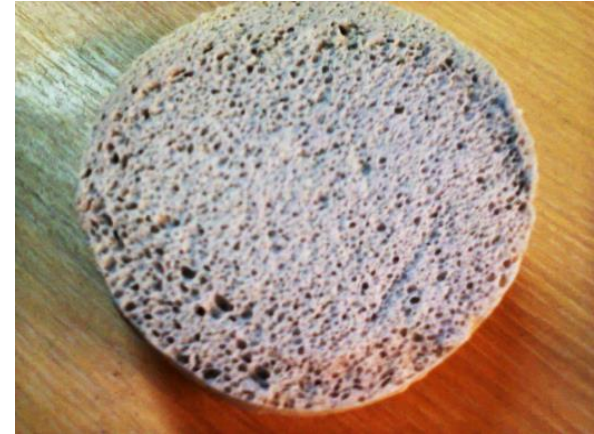

$\mathbf{a}$

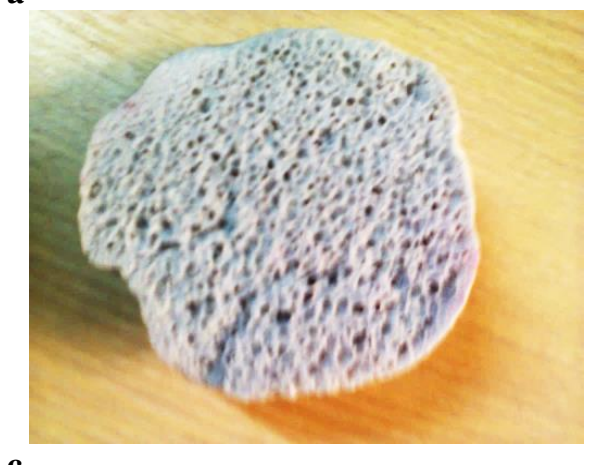

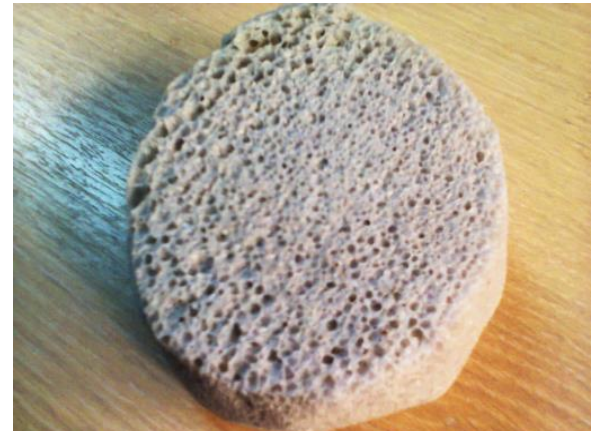

$\mathbf{b}$

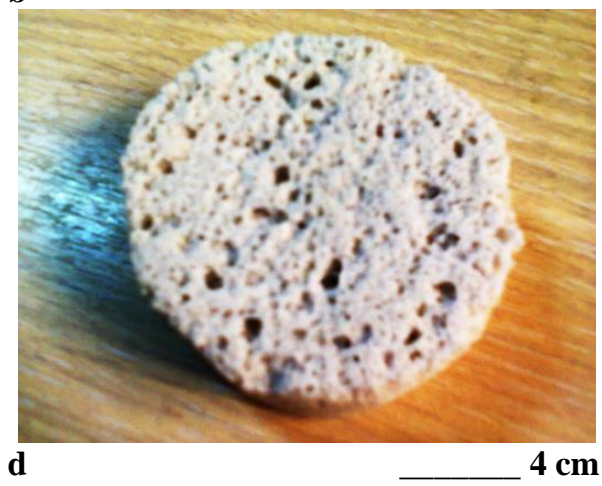

Fig. 2. Cross section of glass foam samples: a - sample 1 sintered at $1013{ }^{\circ} \mathrm{C}$; b - sample 2 sintered at $1031{ }^{\circ} \mathrm{C}$; c - sample 3 sintered at $1050{ }^{\circ} \mathrm{C} ; \mathrm{d}$ - sample 4 sintered at $1072{ }^{\circ} \mathrm{C}$.

In contrast, the compressive strength increased significantly from the value corresponding to the minimum clay content $(2.8 \mathrm{MPa})$ to that corresponding to the maximum content $(6.2 \mathrm{MPa})$, demonstrating the theoretically known influence of clay on the mechanical properties of a foamed material [14]. Due to the consistent presence of clay in the composition of glass foam, the proportion of water absorption was quite high (between 4.8-7.6\%), the clay content directly influencing this material characteristic.

The pore size increased from $0.10-0.30 \mathrm{~mm}$ corresponding to sample 1 , to $0.30-0.60 \mathrm{~mm}$ corresponding to sample 4. The microstructural characteristic of the four glass foam samples can be observed in Figure 3.

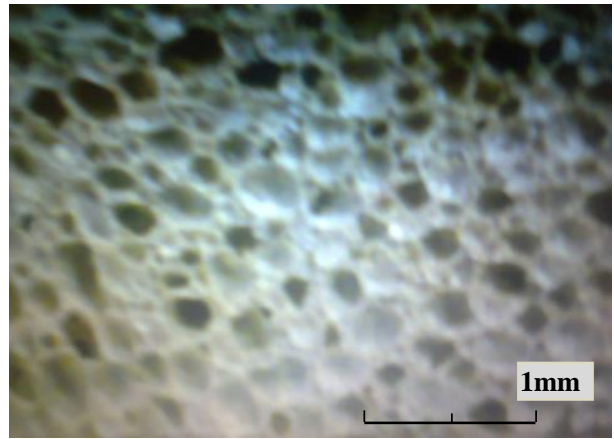

$\mathbf{a}$

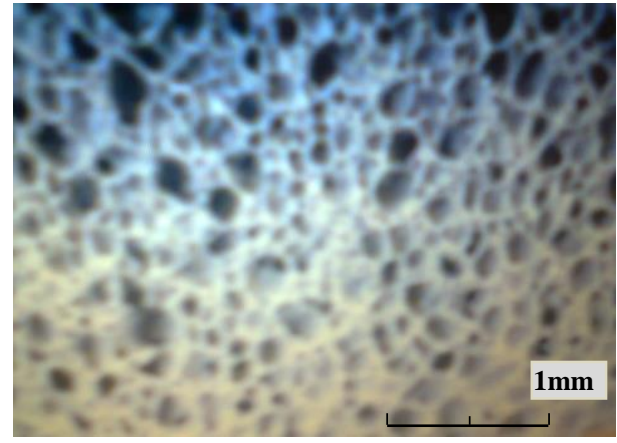

b 


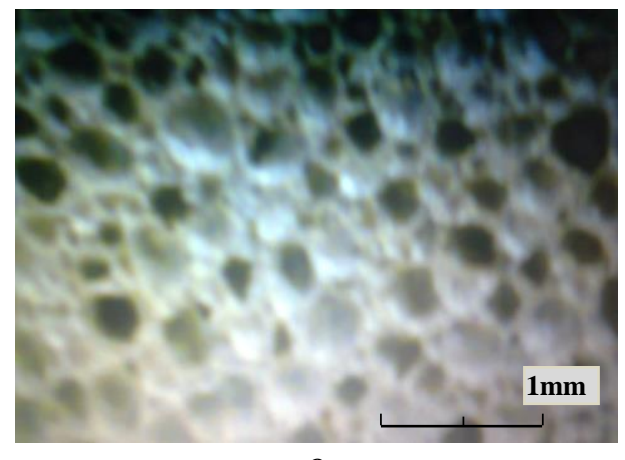

c

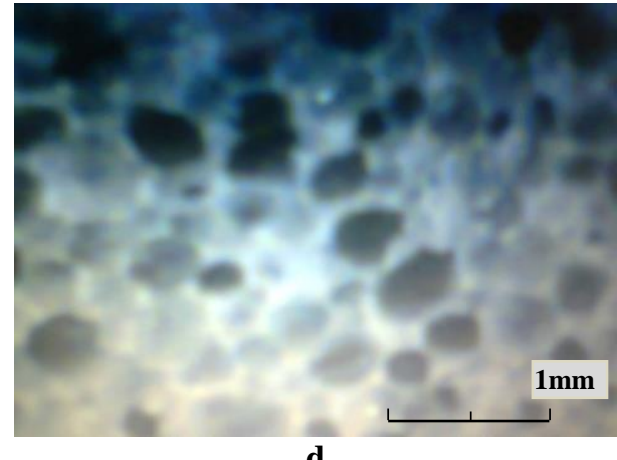

d

Fig. 3. Microstructural images of the glass foam samples:

a - sample 1 sintered at $1013{ }^{\circ} \mathrm{C} ; \mathrm{b}$ - sample 2 sintered at $1031{ }^{\circ} \mathrm{C}$; c - sample 3 sintered at $1050{ }^{\circ} \mathrm{C}$; d - sample 4 sintered at $1072{ }^{\circ} \mathrm{C}$.

With the increase of the clay content, a slight inhomogeneity of the pore distribution appeared, more obviously visible in Figure 2d.

\subsection{Discussion}

Analyzing the functional parameters of the manufacturing process and the main physical, thermal, mechanical and morphological characteristics of glass foams it was considered that the optimal glass foam sample was that corresponding to the experimental variant 3. Made of $78.5 \mathrm{wt} . \%$ colorless glass waste, $18.0 \mathrm{wt} . \%$ kaolin clay powder, $3.5 \mathrm{wt} . \%$ dolomite powder and $20.0 \mathrm{wt}$.\% water addition by sintering at $1050{ }^{\circ} \mathrm{C}$ for 46 min, the best glass foam had the apparent density of $0.66 \mathrm{~g} \cdot \mathrm{cm}^{-3}$, the porosity of $68.6 \%$, the thermal conductivity of 0.155 $\mathrm{W} / \mathrm{m} \cdot \mathrm{K}$, the compressive strength of $5.3 \mathrm{MPa}$, the water absorption of $6.7 \%$ and a microstructural homogeneity with pore size between $0.20-0.50 \mathrm{~mm}$. The justification of the choice took into account all the physical, thermal and mechanical characteristics of the products and the influence of their microstructure on the mentioned characteristics. Thus, the product made in variant 3 had good thermal insulation properties (sufficiently low density and thermal conductivity) and a high compressive strength. Although with a higher mechanical strength, sample 4 was excluded due to the microstructural inhomogeneity, which can negatively influence the uniformity of the thermal insulation of the material. The specific energy consumption of manufacturing process of the optimal product was low $(0.99 \mathrm{kWh} / \mathrm{kg})$, within the usual consumption limits experimentally achieved by using the microwave radiation, especially since the required process temperature was above $1000{ }^{\circ} \mathrm{C}$.

The application of the technical solution of consistent additions of kaolin clay in the mixture of glass-based raw material proved to be suitable for the purpose of obtaining porous products with high mechanical strength. Previously, the authors tested waste containing clay from demolition of buildings [21, 25, 31, 32]. The results were almost similar, although the manufacturing recipes also included coal ash as a raw material and a more effective foaming agent (silicon carbide). Although much cheaper and less used in foaming processes, dolomite has provided the expected effect in this type of process.

The application domain of the product manufactured by this technique is the thermal insulation of the external walls of buildings under conditions of moderate mechanical stress.

Compared to conventional glass foam manufacturing techniques, the application of the unconventional technique based on microwave energy has proven its remarkable energy efficiency. Under the conditions of small-scale experimental processes, with discontinuous operation, the values of specific energy consumption were, generally, close to the level of similar industrial processes (between 0.7-1.0 kWh/kg). According to [16], industrial-scale microwave equipment would have an energy efficiency up to $25 \%$ higher than a low power oven $(0.8 \mathrm{~kW})$ of the type used in the experiments described in this paper.

\section{CONCLUSIONS}

The aim of the research described in the paper was the experimental manufacture by unconventional technique of microwave heating (which is the originality of the paper) of a porous glass foam with high mechanical strength. 
As a basic raw material it was used a colorless container glass waste (between 75.3-84.9 wt.\%), kaolin clay powder (between 12-21 wt.\%), dolomite powder (between 3.1-3.7 wt.\%) as a foaming agent and water addition in a constant ratio of $20 \mathrm{wt} . \%$.

The main functional parameter of the process were: sintering/foaming temperature (between $1013-1072{ }^{\circ} \mathrm{C}$ ), heating time (between 40-50 $\mathrm{min}$ ), average heating rate (between $21.0-25.3{ }^{\circ} \mathrm{C} / \mathrm{min}$ ), average cooling rate (between 6.4-6.6 ${ }^{\circ} \mathrm{C} / \mathrm{min}$ ), index of volume growth (between 1.30-1.80) and specific energy consumption (between $0.89-1.10 \mathrm{kWh} / \mathrm{kg}$ ).

The experiments have produced four variants of porous materials with good thermal insulation characteristics (apparent densities between $0.63-0.69 \mathrm{~g} \cdot \mathrm{cm}^{-3}$ and thermal conductivities between $0.155-0.161 \mathrm{~W} / \mathrm{m} \cdot \mathrm{K}$ ) and compressive strength with variable values between 2.8-6.2 $\mathrm{MPa}$. The highest compressive strength values corresponded to variants with the highest clay contents. The products performed with clay content between $12-$ $18 \mathrm{wt} . \%$ had a homogeneous structure with low pores, while the product made with the maximum clay content (21 wt.\%) had a slight structural inhomogeneity, the pores distribution being uneven.

The product corresponding to variant 3, made of $78.5 \mathrm{wt} \%$ colorless glass waste, $18.0 \mathrm{wt} . \%$ kaolin clay powder, $3.5 \mathrm{wt} . \%$ dolomite powder and $20.0 \mathrm{wt}$. $\%$ water addition by sintering at $1050{ }^{\circ} \mathrm{C}$ for 46 min was considered the best glass foam. The optimal product had the apparent density of $0.66 \mathrm{~g} \cdot \mathrm{cm}^{-3}$, the porosity of $68.6 \%$, the thermal conductivity of $0.155 \mathrm{~W} / \mathrm{m} \cdot \mathrm{K}$, the compressive strength of $5.3 \mathrm{MPa}$, the water absorption of $6.7 \%$ and a microstructural homogeneity with pore size between $0.20-0.50 \mathrm{~mm}$.

The specific energy consumption of manufacturing process of the optimal product was low $(0.99 \mathrm{kWh} / \mathrm{kg})$, within the usual consumption limits experimentally achieved by using the microwave radiation, especially since the required process temperature was above $1000^{\circ} \mathrm{C}$.

The application domain of these products is the thermal insulation of the external walls of buildings under conditions of moderate mechanical stress.

\section{REFERENCES}

[1] Scarinci, G., Brusatin, G., Bernardo, E., Glass foams in cellular ceramics: structure, manufacturing, properties and applications, Ed. Wiley-VCH Verlag GmbH \& Co KGaA, Weinheim (Germany), 2005, p. 158176.

[2] Cosmulescu, F., Paunescu, L., Dragoescu, M.F., Axinte, S.M., Comparative analysis of the foam glass gravel types experimentally produced by microwave irradiation, Journal of Engineering Studies and Research, vol. 26, no. 3, 2020, p. 58-68.

[3] Dragoescu, M.F., Paunescu, L., Porous material from recycled glass waste as an alternative to existing building materials, Constructii, vol. 21, no. 2, 2020, pp. 48-56.

[4] https://www.dir.indiamart.com>impcat/dolomite.html (15.01.2021).

[5] https://www.dir.indiamart.com>impcat/calcium-carbonate-powder.html (16.01.2021).

[6] https://www.dir.indiamart.com>impcat/silicon-carbide.html (14.09.2019).

[7] Pokorny, A., Vicenzi, J., Pérez Bergman, C., Influence of heating rate on the microstructure of glass foams, Waste Management and Research, vol. 29, no. 2, 2011, p. 172-179.

[8] Fernandes, H.R., Tulyaganov, D.U., Ferreira, J.M.F., Preparation and characterization of foams sheet glass and fly ash using carbonates as foaming agents, Ceramics International, vol. 35, no. 1, 2009, p. $229-235$.

[9] Fernandes, H.R., Ferreira, D.D., Andreola, F., Lancellotti, I., Barbieri, L., Ferreira, J.M.F., Environmental friendly management of CRT glass by foaming with waste egg shale, calcite or dolomite, Ceramics International, vol. 40, no. 8, 2014, p. 13371-13379.

[10] Fiume, E., Tulyganov, D., Ubertalli, G., Verné, R., Baino, F., Dolomite-foamed bioactive silicate scaffolds for bone tissue repair, Materials (Basel), vol. 13, no. 3, 2020, p. 628-646. https://www.doi.org/10.3390/ma13030628 (14.01.2021).

[11] Wattanasiriwech, S., Yanya, H., Thanomsilp, C., Manomaivibool, P., Wattanasiriwech, D., Effects of foaming agent contents and firing temperatures on porosity and density of granulated foam glass prepared from waste glass, Industrial Technology Lampang Raabhat University Journal, 2019, p. 84-95. 
[12] Bumanis, G., Vitola, L., Pundiene, I., Sinka, M., Bajare, D., Gypsum, geopolymers, and starch-alternative binders for bio-based building materials: a review and life-cycle assessment, Sustainability, vol. 12, July 2020, https://www.mdpi.com/2071-1050/12/14/5666 (06.02.2021).

[13] Musafirova, G.Y., Musafirov, E.V., Lyshchik, M.V., Block foam glass based on cullet, dolomite flour and liquid glass, Technique and Technology of Silicates, no. 1, 2017, p. 7-11.

[14] Ercenk, E., The effect of clay on foaming and mechanical properties of glass foam insulating material, Journal of Thermal Analysis and Calorimetry, vol. 127, 2017, p. 137-146.

[15] Paunescu, L., Dragoescu, M.F., Axinte, S.M., Use of natural dolomite as a cheap foaming agent for producing glass foams from glass waste in the microwave field, Journal of Engineering Studies and Research, vol. 26, no.1, 2020, p. 57-64.

[16] Kharissova, O., Kharissov, B.I., Ruiz Valdés, J.J., Review: the use of microwave irradiation in the processing of glasses and their composites, Industrial and Engineering Chemistry Research, vol. 49, no. 4, 2010, p. 1457-1466.

[17] Olszak-Humienik, M., Jablonski, M., Thermal behavior of natural dolomite, Journal of Thermal Analysis and Calorimetry, vol. 119, no. 3, 2015, p. 2239-2248.

[18] Weast, R.C., CRC Handbook of Chemistry and Physics (59th edition), West Palm Beach, Florida, CRC Press, 1978-1979, p. B-133.

[19] Jones, D.A., Lelyveld, T.P., Mavrofidis, S.D., Kingman, S.W., Miles, N.J., Microwave heating applications in environmental engineering - a review, Resources, Conservation and Recycling, vol. 34, no. 2, 2002, p. 75 90.

[20] Kitchen, H.J., Vallance, S.R., Kennedy, J.L., Tapia-Ruiz, N., Carassiti, L., Harrison, A., Whittaker, A.G., Drysdale, T.D., Kingman, S.W., Gregory, D.H., Modern microwave methods in solid-state inorganic materials chemistry: From fundamentals to manufacturing, Chemical Reviews, vol. 114, no. 2, 2014, p. 1170-1206.

[21] Paunescu, L., Dragoescu, M.F., Axinte, S.M., Thermal insulating material with high mechanical strength made from clay brick waste and coal ash using the microwave energy, Journal of Engineering Studies and Research, vol. 26, no. 2, 2020, p. 28-34.

[22] Paunescu, L., Dragoescu, M.F., Axinte, S.M., Cosmulescu, F., Nonconventional manufacture technique of cellular glass from recycled aluminosilicate glass-based waste, Material Science and Engineering International Journal, vol. 5, no. 1, 2021, p.11-16.

[23] http://www.glassproperties.com/glasses/ (02.06.2018).

[24] Yahaga, S., Jikan, S.S., Badarulzaman, N.A., Adamu, A.D., Chemical composition and particle size analysis of kaolin, Traektoriâ Nauki-Path of Science, vol. 3, no. 10, 2017, https://doi.org/10.22178/pas.27-1 (01.02.2021). [25] Dragoescu, M.F., Paunescu, L., Axinte, S.M., Sebe, A.C., Nonconventional heating technique to produce glass-ceramic foam from glass waste and old clay brick waste, Nonconventional Technologies Review, vol. 23, no. 2, 2019, p. 58-62.

[26] Manual of weighing applications, Part 1-Density, 1999, http://www.docplayer.net/21731890-Manual-ofweighing-applications-part-1-density_html (22.02.2017).

[27] Anovitz, L.M., Cole, D.R., Characterization and analysis of porosity and pore structures, Reviews in Mineralogy and Geochemistry, vol. 80, 2005, p. 61-164.

[28] ASTM C552-17, Standard specification for cellular glass thermal insulation, 2017.

[29] Yüksel, N., The review of some commonly used methods and techniques to measure the thermal conductivity of insulation materials, August 2016, https://doi.org/10.5772/64157 (20.02.2021).

[30] ASTM D570-98(2018), Standard test method for water absorption of plastics. https://www.astm.org/Standards/D570 (15.02.2021).

[31] Paunescu, B.V., Paunescu, L., Lightweight aggregate made by microwave irradiation, Constructii, vol. 21, no. 2, 2020, p. 57-63.

[32] Paunescu, L., Dragoescu, M.F., Axinte, S.M., Sebe, A.C., Lightweight aggregate from recycled masonry rubble achieved in microwave field, Nonconventional Technologies Review, vol. 23, no. 2, 2019, p. 47-51. 